\title{
Upregulation of microRNA-204 inhibits cell proliferation, migration and invasion in human renal cell carcinoma cells by downregulating SOX4
}

\author{
DEYAO WU $^{1 *}$, HUIXING PAN $^{1 *}$, YUNFENG ZHOU $^{1}$, ZICHUN ZHANG $^{1}$, \\ PING QU $^{1}$, JIAN ZHOU ${ }^{1}$ and WANXIANG WANG ${ }^{2}$ \\ ${ }^{1}$ Department of Urology; ${ }^{2}$ Inspection Branch, The Fourth Affiliated Hospital of Nantong Medical College, \\ Yancheng City No. 1 People's Hospital, Yancheng, Jiangsu 224001, P.R. China
}

Received November 11, 2014; Accepted August 7, 2015

DOI: $10.3892 / \mathrm{mmr} .2015 .4259$

\begin{abstract}
MicroRNA-204 (miR-204) has been reported to be frequently downregulated in various types of cancer, including renal, brain, ovary, hematological and colon cancer. The present study, investigated the effects of miR-204 on renal cell carcinoma. Following transfection of miR-204, an MTT assay, cell migration assay, cell invasion assay, western blot analysis and luciferase assay were performed in renal cell carcinoma cell lines. It was demonstrated that miR-204 inhibits cell proliferation, migration and invasion in 786-O and A498 cells. To the best of our knowledge, this study is the first to demonstrate that miR-204 directly targets SOX4 in renal cell carcinoma. These results suggested that miR-204 may have value as a marker for the early detection of tumor metastasis and a therapeutic target preventing the invasion of renal cell carcinoma.
\end{abstract}

\section{Introduction}

Renal cell carcinoma (RCC) is the most common type of kidney malignancy. In addition it is the third most common type of urological cancer after prostate and bladder cancer; however, it has the highest mortality rate of the three at $>40 \%$. Among the five subtypes of RCC, clear cell carcinoma (CCC) accounts for $\sim 70 \%$ of cases (1). Although the majority of patients with early-stage RCC can be cured surgically, 33\%

Correspondence to: Professor Jian Zhou, Department of Urology, The Fourth Affiliated Hospital of Nantong Medical College, Yancheng City No. 1 People's Hospital, 15 Yuehe Road, Yancheng, Jiangsu 224001, P.R. China

E-mail: luqiang0405@163.com

Professor Wanxiang Wang, Inspection Branch, The Fourth Affiliated Hospital of Nantong Medical College, Yancheng City No. 1 People's Hospital, 15 Yuehe Road, Yancheng, Jiangsu 224001, P.R. China E-mail:kjk8915@126.com

${ }^{*}$ Contributed equally

Key words: renal cell carcinoma, SOX4, microRNA-204 of patients present with synchronous metastatic disease for which treatment is usually not curative (2). The most common sites of metastatic spread in RCC are the lung, bone, adrenal gland, liver and brain, whereupon more than one organ system is often involved in the metastatic process (3). In addition, RCC is relatively resistant to radiotherapy and chemotherapy, which result in the poor prognosis of patients with RCC with metastatic or recurrent disease and a 5-year survival rate of $<20 \%$ (4). A number of studies have identified putative oncogenes involved in the carcinogenesis of RCC; however, the molecular mechanisms regulating the aggressive properties of RCC remain poorly understood $(5,6)$. Hence, novel treatments are required to improve the prognosis of patients with RCC.

MicroRNAs (miRNAs), which are a highly conserved class of short non-coding endogenous RNAs comprising 22 nucleotides, are endogenously expressed across mammals and other species (7). Production and function of miRNA requires a set of proteins collectively referred to as the miRNA machinery (8). Primary miRNA transcripts are first processed into precursor microRNA (pre-miRNA). This step requires a $650-\mathrm{kDa}$ microprocessor complex that comprises of Drosha, RNase III endonuclease and DGCR8 (9-12). These pre-miRNAs are then actively transported by Exportin- 5 to the cytoplasm, where they are further processed by the cytoplasmic RNase III enzyme Dicer (13-15). Finally, Argonaute proteins are recruited with miRNAs into an RNA-induced silencing complex for mRNA recognition (16). It has attracted attention for its involvement in cell differentiation, development, apoptosis and proliferation by targeting mRNAs for cleavage or translational repression at the posttranscriptional level (17). The inappropriate expression of miRNAs can lead to the aberrant expression of gene products that may contribute to the acquisition of the hallmarks of cancer (18). Upregulated miRNAs in cancer may function as oncogenes by negatively regulating tumor suppressors. By contrast, downregulated miRNAs may normally function as tumor suppressor genes and inhibit cancer by regulating oncogenes $(19,20)$.

miR-204 has been reported to be frequently downregulated in various types of cancer, including brain, kidney, ovarian, hematological and colon cancer (20). However, the function of miR-204 has not yet been investigated in RCC. The aim of 
this study was to elucidate the effect of miR-204 on RCC and to investigate its underlying mechanisms.

\section{Materials and methods}

Cell lines and cell culture. The 786-O and A498 human RCC cell lines were purchased from the Shanghai Institute of Cell Biology, Chinese Academy of Science (Shanghai, China). The cells were cultured in RPMI-1640 (HyClone, Logan, UT, USA) medium supplemented with $10 \%$ heat-inactivated fetal calf serum (Gibco-BRL, Grand island, NY, USA), $100 \mathrm{U} / \mathrm{ml}$ penicillin and $100 \mathrm{mg} / \mathrm{l}$ streptomycin (Gibco-BRL) under a humidified atmosphere of $5 \% \mathrm{CO}_{2}$ at $37^{\circ} \mathrm{C}$.

Transient transfection of miRNA mimics and luciferase reporter plasmids. The miR-204 mimics, negative control (NC) and luciferase reporter plasmid were designed and synthesized by GenePharma (Shanghai, China). The insertion fragment was confirmed by DNA sequencing. Cell transfection and cotransfection were performed using Lipofectamine ${ }^{\mathrm{TM}} 2000$ (Invitrogen Life Technologies, Carlsbad, CA, USA) according to manufacturer's instructions. Following transfection, cells were incubated at $37^{\circ} \mathrm{C}$ until assessment.

Cell viability assay. Cell proliferation was measured using the 3-(4,5-dimethylthiazol-2-yl)-2,5-diphenyl-2H-tetrazolium bromide (MTT) method (Sigma-Aldrich). After $48 \mathrm{~h}$ transfection, the cells were trypsinized (Gibco-BRL) and counted, respectively. Cells were counted under a microscope (CKX41; Olympus, Tokyo, Japan). Cells were plated in each well of 96-well plates at a density of 3,000 cells per well and incubated at $37^{\circ} \mathrm{C}$. Cell proliferation was documented every $24 \mathrm{~h}$ for 5 days according to the manufacturer's instructions. Absorbance was measured at $490 \mathrm{~nm}$ using an automatic multi-well spectrophotometer (Bio-Rad, Richmond, CA, USA). There were six wells for every time point in each group. The growth inhibition rate was calculated using the following equation: Growth inhibition rate $=\left(1-\mathrm{OD}_{\text {miR-204 }} / \mathrm{OD}_{\text {miR-NC }} \times 100\right.$; where OD is the optical density. All the experiments were performed in triplicate.

Migration and invasion assay. In vitro cell migration and invasion assays were performed using $8 \mu \mathrm{m}$-pore polycarbonate membrane Boyden chamber inserts in a Transwell apparatus (Costar, Cambridge, MA, USA). The transfected cells (miR-204 mimics and negative control) growing in the log phase were treated with trypsin/EDTA solution (Gibco-BRL), washed once with no serum-containing medium, centrifuged at $200 \mathrm{x} \mathrm{g}$ for $5 \mathrm{~min}$ and re-suspended as single-cell solutions in no-serum containing medium. For the migration assays, $1 \times 10^{5}$ cells in $200 \mu \mathrm{l}$ serum-free RPMI-1640 medium were seeded on the upper chamber of transwell apparatus. For the invasion assays, $1 \times 10^{5}$ cells were added to the upper chamber of the transwell precoated with $30 \mu \mathrm{g}$ Matrigel (BD Biosciences, San Jose, CA, USA). In these assays, $600 \mu 1$ RPMI-1640 containing $20 \%$ fetal calf serum was added to the lower chamber, serving as a chemoattractant. After $12-24 \mathrm{~h}$ at $37^{\circ} \mathrm{C}$ in a $5 \% \mathrm{CO}_{2}$ incubator, the cells that had not migrated or invaded through the pores were carefully removed with a cotton swab. The filters were then fixed in $100 \%$ methanol for $2 \mathrm{~min}$, stained in $0.5 \%$ crystal violet (Beyotime Institute of Biotechnology, Haimen,
China) for $2 \mathrm{~min}$, rinsed in phosphate-buffered saline and then subjected to microscopic inspection (CKX41; Olympus). Values for migration and invasion were obtained by counting five fields per membrane and represent the average of three independent experiments.

Western blot analysis. Primary antibodies used in this study including rabbit anti-human monoclonal SOX4 (1:500; cat. no. BS8784) and mouse anti-human monoclonal $\beta$-actin $(1: 1,000$; cat. no. AP0060) were purchased from Bioworld Technology (Louis Park, MN, USA). Total protein of cells extracts were prepared in radioimmunoprecipitation assay lysis buffer (Beyotime Institute of Biotechnology). Protein concentration in the resulting lysate was performed using a Bicinchoninic Acid Protein assay kit (Thermo Fisher Scientific, Inc., Rockford, IL, USA) according to the manufacturer's instructions. Briefly, equal quantities of protein were loaded onto a 10\% SDS-PAGE gel (Beyotime Institute of Biotechnology) and electroblotted onto a polyvinylidene difluoride membrane (Millipore, Billerica, MA, USA). The membranes were blocked in phosphate-buffered saline containing $0.1 \%$ Tween-20 (Beyotime Institute of Biotechnology) and 5\% non-fat dry milk. The membranes were incubated with primary antibody overnight at $4^{\circ} \mathrm{C}$. Following washing, the membranes were incubated with the corresponding horseradish peroxidase-conjugated secondary antibody (Bioworld Technology) in Tris-buffered saline with Tween-20. The bands were then developed using an ECL solution (Pierce Biotechnology, Inc., Rockford, IL, USA) and images were captured using a FluorChem imaging system (Alpha Innotech, San Leandro, CA, USA). The intensity of each spot was read and analyzed with AlphaEaseFC software. $\beta$-actin was used as a loading control.

Luciferase assay. TargetScan 5.2 (http://www.targetscan.org/) and PicTar (http://pictar.mdc-berlin.de/) were used to assess the complementarity of miR-204 to the SOX4 3'-UTR. Luciferase reporter assays were performed to evaluate whether SOX4 is a target of miR-204. Cells were plated in a 12-well plate and transfected with $0.5 \mu \mathrm{g}$ reporter plasmid, $40 \mathrm{nmol} \mathrm{miR-204}$ mimics or their negative control. Transfection was performed using Lipofectamine 2000. Each sample was also cotransfected with $0.05 \mu \mathrm{g}$ pRL-CMV plasmid expressing Renilla Luciferase (Promega Corporation, Madison, WI, USA) as an internal control for transfection efficiency. Relative luciferase activity was calculated $48 \mathrm{~h}$ post-transfection by the Dual Luciferase Reporter Assay kit (Promega Corporation). Firefly luciferase activity was normalized to Renilla luciferase activity for each transfected well. Each assay was replicated three times.

Statistical analysis. Data are presented as the mean \pm standard deviation, and compared using Student's t-test in Stata 10.0 (College Station, Texas, USA). Double-tailed $\mathrm{P}<0.05$ was considered to indicate a statistically significant difference.

\section{Results}

miR-204 suppresses cell proliferation in RCC cell lines. The effect of miR-204 on 786-O and A498 cell proliferation was investigated using MTT assays. The data showed significant 

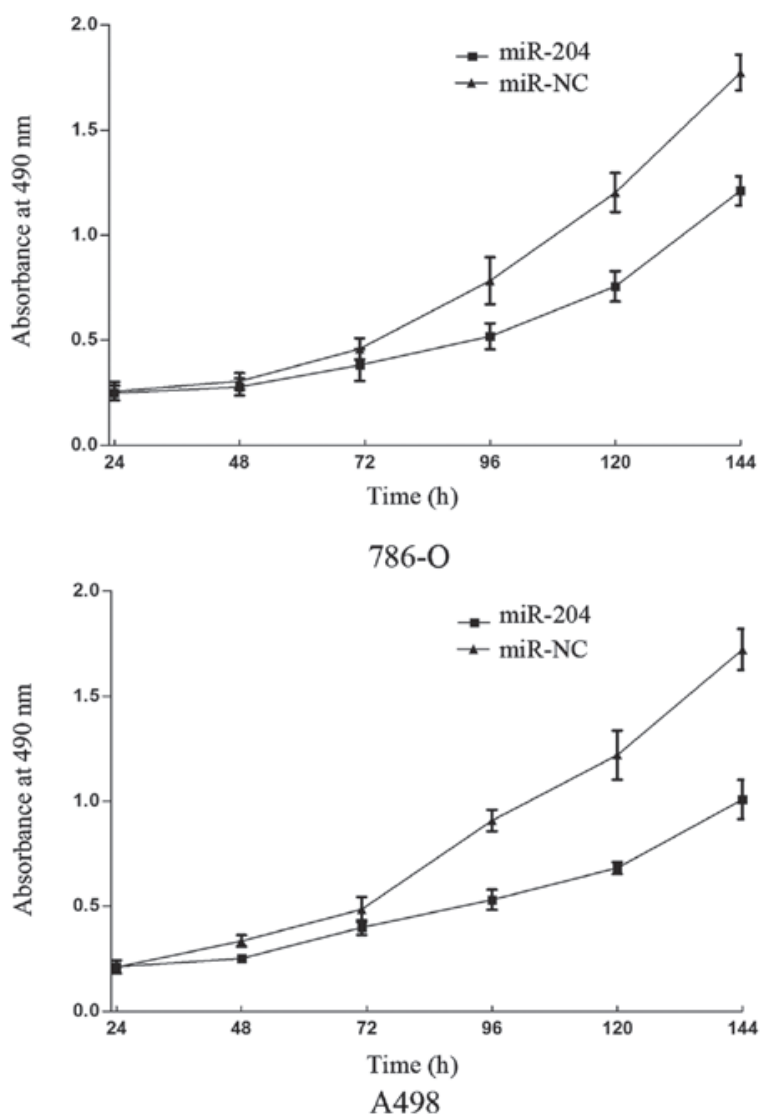

Figure 1. Viability of 786-O and A498 cells following transfection of miR-204. The cell proliferation was determined by a 3-(4,5-dimethylthiazol-2-yl)-2,5-diphenyl-2H-tetrazolium bromide assay. The results indicated that upregulation of miR-204 significantly suppressed cell proliferation. miR, microRNA; NC, negative control.

cell growth inhibition in the miR-204 transfectant compared with the control from 786-O and A498 cell lines $(\mathrm{P}<0.05)$. As shown in Fig. 1, MTT assays revealed that after $144 \mathrm{~h}$ of treatment, the suppression rate of miR-204 reached $29.12 \pm 3.5 \%$ in $786-\mathrm{O}$ cells and $36.68 \pm 4.5 \%$ in A498 cells. These results indicated that miR-204 may be important in 786-O and A498 cell lines.

miR-204 inhibits cell migration and invasion in RCC cell lines. The Transwell assay was performed to measure the effect of miR-204 on tumor cell migration and invasion. As shown in Fig. 2, cell migration and invasion were significantly decreased in miR-204 group compared with the control group $(\mathrm{P}<0.05)$. These results indicated that miR-204 inhibits the cell migration and invasion in RCC cell lines.

miR-204 suppresses the expression of SOX4 in RCC cell lines. Zhou et al (21) revealed that miR-204 may act as a tumor suppressor in Helicobacter pylori-induced gastric cancer by downregulation of SOX4. Western blot analysis was performed to determine whether the SOX4 protein level decreased following overexpression of miR-204. As shown in Fig. 3, SOX4 expression was significantly decreased in 786-O and A498 cells after transfection of miR-204 $(\mathrm{P}<0.05)$. Thus, miR-204 reduces the protein level of SOX4 in 786-O and A498 RCC cell lines.
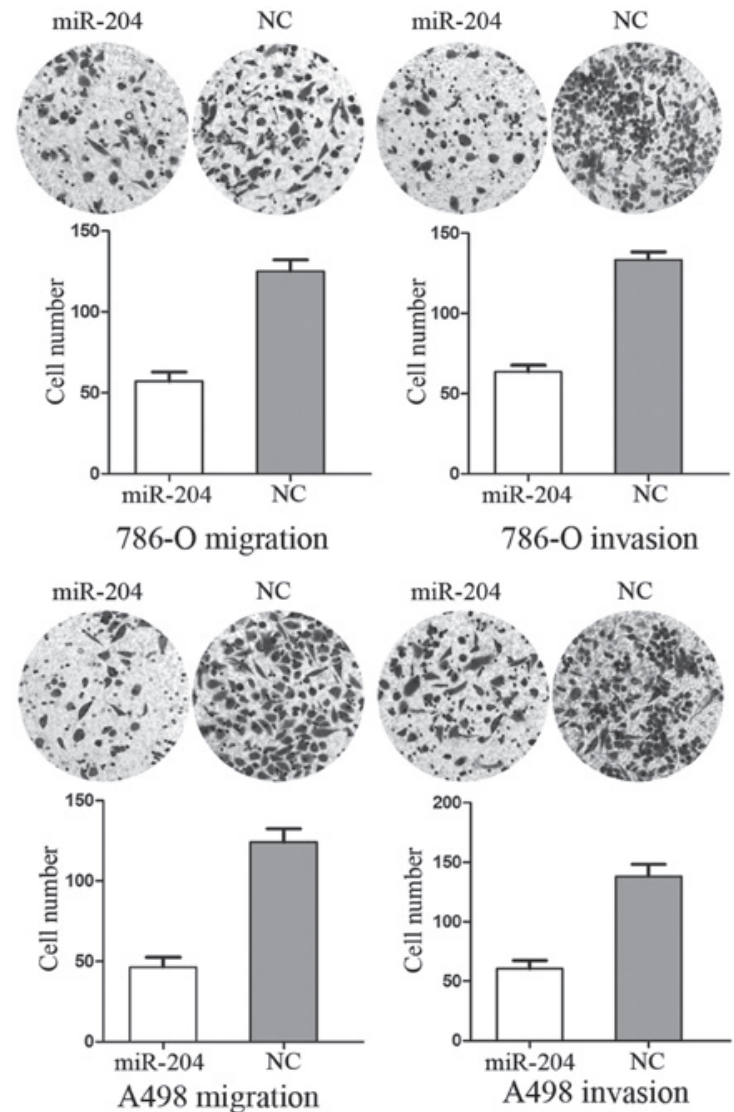

Figure 2. miR-204 inhibits cell migration and invasion in 786-O and A498 cells. Cell migration and invasion were significantly decreased in the miR-204 groups compared with the control group. miR, microRNA; NC negative control.

SOX4 is a direct target of $m i R-204$. To determine whether miR-204 targets the SOX4 3'-untranslated region (UTR), TARGETSCAN 5.2 (http://www.targetscan.org/) and PICTAR (http://pictar.mdc-berlin.de/) were used to assess the complementarity of miR-204 to the SOX4 3'-UTR. It was shown that SOX4 mRNA contained an miR-204 seven-nucleotide seed match at position 2057-2063 of the SOX4 3'-UTR (shown in Fig. 4A).

Luciferase reporter assays were performed to evaluate whether the site could directly mediate expression inhibition. As shown in Fig. 4B, upregulation of miR-204 suppressed SOX4 3'UTR-luciferase activity by $67 \%$ in $786-\mathrm{O}$ cells and $55 \%$ in A498 cells $(\mathrm{P}<0.05)$. Thus, SOX4 may be a direct target of miR-204 in vitro.

\section{Discussion}

miRNAs have emerged as a novel mechanism of gene regulation in recent years. To date, there are 1,527 human miRNAs and 741 mouse miRNAs registered in the miRBase (http://www.mirbase.org/) (22-24). However, thousands of miRNAs in various genomes and their targets still require validation (23). Investigation of the differentially expressed miRNAs in cancer specimens has yielded important information on carcinogenesis (25). Although RCC generally carries a favorable prognosis, patients with metastatic RCC face a poor prognosis and have limited therapeutic options. The median 

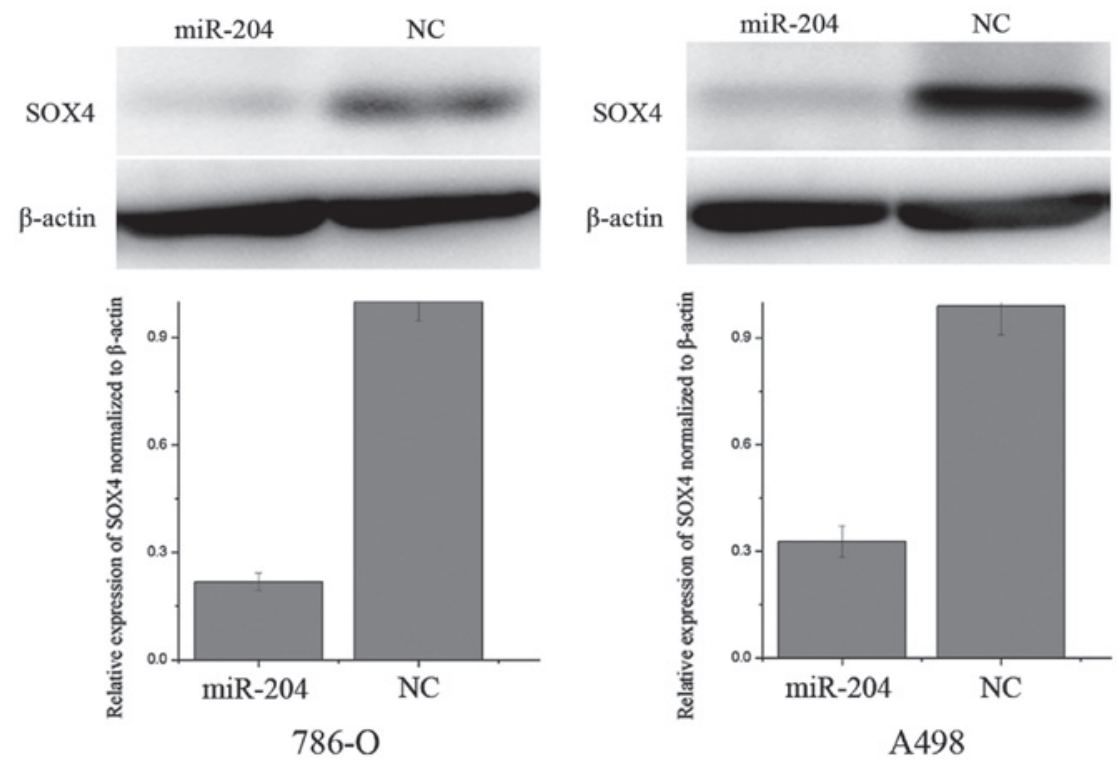

Figure 3. SOX4 was significantly lowered in 786-O and A498 cells after transfection of miR-204. miR, microRNA; NC, negative control.

A

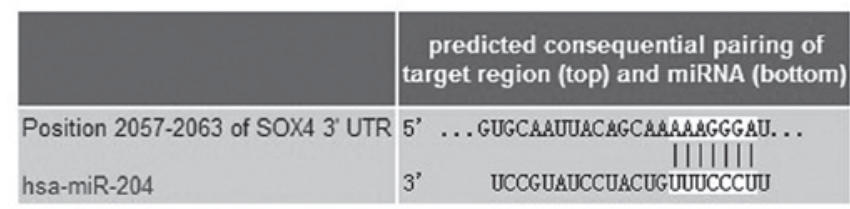

B
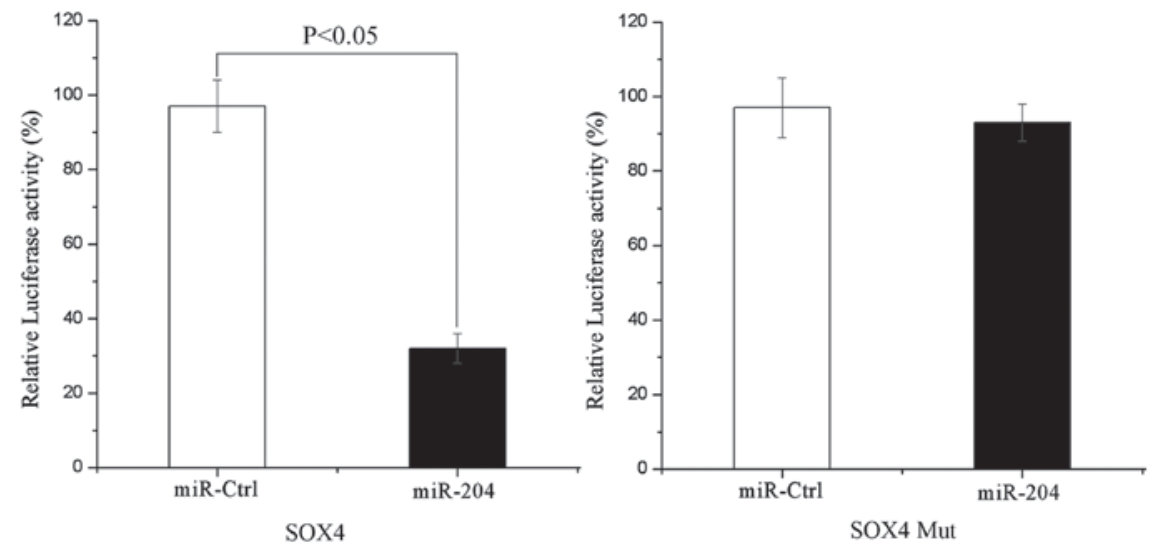

$786-0$
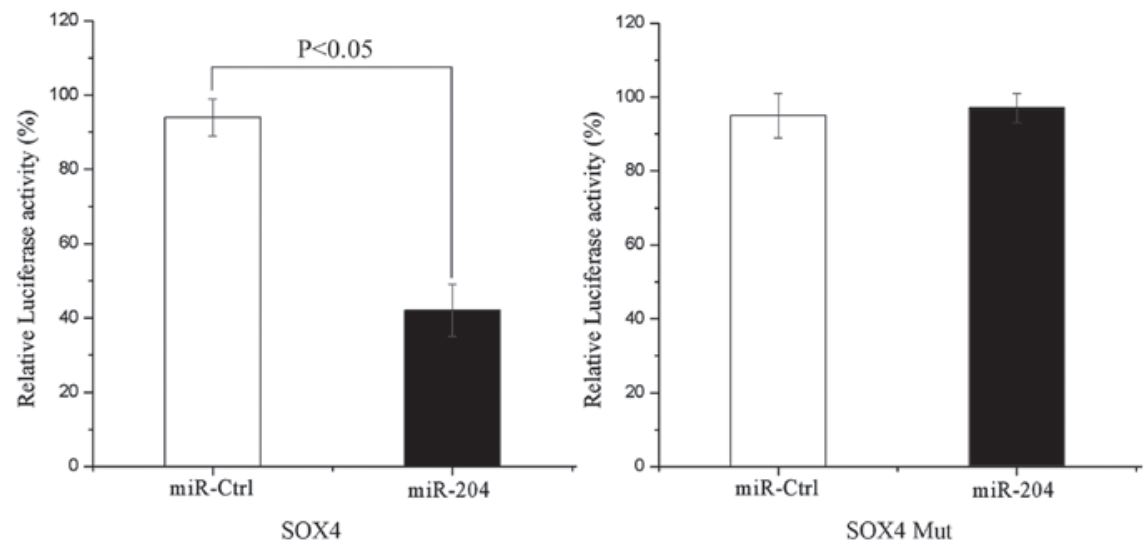

A498

Figure 4. (A) TARGETSCAN 5.2 and PICTAR demonstrated that SOX4 mRNA contained an miR-204 seven-nucleotide seed match at position 2057-2063 of the SOX4 3'-UTR. (B) SOX4 may be a direct target of miR-204 in vitro. miR-204 could suppress SOX4 3'UTR-luciferase activity by $67 \%$ in $786-\mathrm{O}$ cells and $55 \%$ in A498 cells after transfection of miR-204. miR, microRNA; UTR, untranslated region. 
survival rate in a recent cohort was only 1.5 years with $<10 \%$ of patients surviving 5 years after the initial diagnosis (26). Therefore, it is important to determine the molecular pathways involved in RCC in order to improve the diagnosis of and therapeutic options for the disease.

miR-204, is located at the cancer-associated genomic 9q21.1-q22.3 locus and exhibits a high frequency of loss of heterozygosity in certain types of tumor (27-29). It is also located within the sixth intron of the host gene transient receptor potential melastatin 3 cation channel and is transcribed in the same direction as TRPM3 (30). The expression of miR-204 was observed to be significantly decreased by $0.07-5 \%$, in tumors in 5 of the 9 tissue types (brain, kidney, ovary, hematological cells, and colon) compared with normal tissues (31). In addition, miR-204 expression was observed to be downregulated in 60 tumor sample tissues compared with 13 matched normal tissues (32). In addition, significant downregulation of miR-204 was found in a subtype of acute myeloid leukemia-bearing cytoplasmic mutated nucleophosmin and in 3 Burkitt B-cell lymphoma cell lines (33). In RCC, the miR-204 level was also found to be decreased as compared with matched normal kidney tissue in paired and unpaired analyses (34). These studies strongly suggest that miR-204 functions as a tumor suppressor.

miR-204 appears to be an important regulator of cell differentiation, apoptosis, stress response, inflammation, lens development, retinal development, and in the maintenance of axonal structure and function (35-38). It has been shown to act as a tumor suppressor in a variety of cancer types through different mechanisms $(34,39,40)$. It also reduced cell migration, invasion, and the formation of metastatic tumors in a variety of squamous cell carcinomas but had no effect on proliferation or viability (41). Identification of miR-204 target genes is critical for understanding the role of miR-204 in tumorigenesis, and is important for determining novel therapeutic targets.

Several mRNA targets have been identified that are important in normal cell development, including MEIS1, HOXA9, MEIS2, RUNX2 and SIRT1 (41). In breast cancer and ovarian cancer cells, miR-204 inhibits cell invasion and metastasis by targeting the stemness-governing transcription factor and the migration-promoting receptor (42). In endometrial cancer, miR-204 was found to regulate cell migration and invasion by targeting the FOXC1 gene (39). In the present study, it was demonstrated that miR-204 transfection resulted in decreased cell proliferation, migration and invasion in RCC cell lines by targeting SOX4. The results suggested that miR-204 may be used for the development of novel molecular markers and therapeutic approaches for RCC.

Sox4, a transcription factor of the sex-determining gene on the $\mathrm{Y}$ chromosome, is characterized by a highly conserved sequence in the high-mobility group (HMG) DNA-binding domain (DBD) (43). SOX4 gene is located on 6p22.3 and encodes a protein of 474 amino acids with three major domains: UA HMG box, a glycine-rich region, and a serine-rich region (44). The HMG box acts as DNA-binding region, whereas the SRR domain serves as transactivation domain. The glycine-rich region, which is located between the HMG box and SRR, is a part of the central domain, and this region has a function in promoting apoptotic cell death (45).
High levels of SOX4 expression have been reported in hepatic cancer cells and a variety of human cancer types, such as breast, brain, lung, pancreatic, salivary gland and ovarian cancer (46). Sox 4 is important in a number of developmental processes, including embryonic cardiac, thymocyte and nervous system development, through its transcriptional activity (47). Besides functioning as a transcription factor involved in the regulation of developmental processes, SOX4 has been implicated in cancer progression. In the case of bladder cancer, upregulated expression of SOX4 was significantly correlated with increased patient survival, and overexpression of SOX4 impaired cell viability and promoted apoptosis in cancer cells (46). Similarly, in patients with melanoma, reduced expression of SOX4 was significantly correlated with poor prognosis and metastasis (48). By contrast, knockdown of SOX4 induced apoptosis in prostate and adenoid cystic cancer cells, and suppressed tumor growth and local metastasis in hepatocellular carcinoma $(49,50)$. Results of the present study indicated that miR-204 suppresses RCC cell proliferation, migration and invasion via downregulation of SOX4, and thus decreasing SOX4 levels may represent a potential therapeutic strategy for RCC.

To the best of our knowledge, the present study is the first to demonstrate that regulation of SOX4 by miR-204 inhibits RCC cell proliferation, migration and invasion. These observations have therapeutic implications and may be exploited further for the treatment of RCC. Future studies are required to determine the potential of miR-204 in cancer treatment and specifically, RCC.

\section{References}

1. Lian JH, Wang WH, Wang JQ, Zhang YH and Li Y: MicroRNA-122 promotes proliferation, invasion and migration of renal cell carcinoma cells through the PI3K/Akt signaling pathway. Asian Pac J Cancer Prev 14: 5017-5021, 2013.

2. Motzer RJ, Bander NH and Nanus DM: Renal-cell carcinoma. N Engl J Med 335: 865-875, 1996.

3. Toma MI, Erdmann K, Diezel M, Meinhardt M, Zastrow S, Fuessel S, Wirth MP and Baretton GB: Lack of ephrin receptor A1 is a favorable independent prognostic factor in clear cell renal cell carcinoma. PloS One 9: e102262, 2014.

4. Yang YQ and Chen J: Predictive role of vascular endothelial growth factor polymorphisms in the survival of renal cell carcinoma patients. Genet Mol Res 13: 5011-5017, 2014.

5. Kardas I, Mrózek K, Babinska M, Krajka K, Hadaczek P Lubinski J, Roszkiewicz A, Kuziemska E and Limon J: Cytogenetic and molecular findings in 75 clear cell renal cell carcinomas. Oncol Rep 13: 949-956, 2005.

6. Girolami F, Passerini I, Gargano D, Frusconi S, Villari D, Nicita G and Torricelli F: Microsatellite analysis of chromosome $3 p$ region in sporadic renal cell carcinomas. Pathol Oncol Res 8: 241-244, 2002.

7. Bartel DP: MicroRNAs: Genomics, biogenesis, mechanism and function. Cell 116: 281-297, 2004.

8. Wu D, Tao J, Xu B, Li P, Lu Q and Zhang W: Downregulation of Dicer, a component of the microRNA machinery, in bladder cancer. Mol Med Rep 5: 695-699, 2012.

9. Han J, Lee Y, Yeom KH, Nam JW, Heo I, Rhee JK, Sohn SY, Cho Y, Zhang BT and Kim VN: Molecular basis for the recognition of primary microRNAs by the Drosha-DGCR8 complex. Cell 125: 887-901, 2006.

10. Lee Y, Ahn C, Han J, Choi H, Kim J, Yim J, Lee J, Provost P, Rådmark O, Kim S and Kim VN: The nuclear RNase III Drosha initiates microRNA processing. Nature 425: 415-419, 2003.

11. Lee Y, Han J, Yeom KH, Jin H and Kim VN: Drosha in primary microRNA processing. Cold Spring Harb Symp Quant Biol 71: $51-57,2006$. 
12. Yeom KH, Lee Y,Han J, Suh MR and Kim VN: Characterization of DGCR8/Pasha, the essential cofactor for Drosha in primary miRNA processing. Nucleic Acids Res 34: 4622-4629, 2006.

13. Bohnsack MT, Czaplinski K and Gorlich D: Exportin 5 is a RanGTP-dependent dsRNA-binding protein that mediates nuclear export of pre-miRNAs. RNA 10: 185-191, 2004.

14. Chendrimada TP, Gregory RI, Kumaraswamy E, Norman J, Cooch N, Nishikura K and Shiekhattar R: TRBP recruits the Dicer complex to Ago2 for microRNA processing and gene silencing. Nature 436: 740-744, 2005.

15. Lund E, Guttinger S, Calado A, Dahlberg JE and Kutay U: Nuclear export of microRNA precursors. Science 303: 95-98, 2004.

16. Berdnik D, Fan AP, Potter CJ and Luo L: MicroRNA processing pathway regulates olfactory neuron morphogenesis. Curr Biol 18: $1754-1759,2008$

17. Fu W, Pang L, Chen Y, Yang L, Zhu J and Wei Y: The microRNAs as prognostic biomarkers for survival in esophageal cancer: A meta-analysis. Scientific World Journal 2014: 523979, 2014.

18. Yuan W, Sui C, Liu Q, Tang W, An H and Ma J: Up-regulation of microRNA-145 associates with lymph node metastasis in colorectal cancer. PloS One 9: e102017, 2014.

19. Esquela-Kerscher A and Slack FJ: Oncomirs - microRNAs with a role in cancer. Nat Rev Cancer 6: 259-269, 2006

20. Calin GA and Croce CM: MicroRNA signatures in human cancers. Nat Rev Cancer 6: 857-866, 2006.

21. Zhou X, Li L, Su J and Zhang G: Decreased miR-204 in H pylori-associated gastric cancer promotes cancer cell proliferation and invasion by targeting SOX4. PloS One 9: e101457, 2014.

22. Kozomara A and Griffiths-Jones S: miRBase: Integrating microRNA annotation and deep-sequencing data. Nucleic Acids Res 39: D152-D157, 2011.

23. Griffiths-Jones S, Saini HK, van Dongen S and Enright AJ miRBase: Tools for microRNA genomics. Nucleic Acids Res 36: D154-D158, 2008

24. Griffiths-Jones S, Grocock RJ, van Dongen S, Bateman A and Enright AJ: miRBase: microRNA sequences, targets and gene nomenclature. Nucleic Acids Res. 34: D140-D144, 2006.

25. Zhou Y, Wu D, Tao J, Qu P, Zhou Z and Hou J: MicroRNA-133 inhibits cell proliferation, migration and invasion by targeting epidermal growth factor receptor and its downstream effector proteins in bladder cancer. Scand J Urol 47: 423-432, 2013.

26. Xue YJ, Xiao RH, Long DZ, Zou XF, Wang XN, Zhang GX, Yuan YH, Wu GQ, Yang J, Wu YT, et al: Overexpression of FoxM1 is associated with tumor progression in patients with clear cell renal cell carcinoma. J Transl Med 10: 200, 2012

27. Bauer VL, Braselmann H, Henke M, Mattern D, Walch A, Unger K, Baudis M, Lassmann S, Huber R, Wienberg J, et al: Chromosomal changes characterize head and neck cancer with poor prognosis. J Mol Med (Berl) 86: 1353-1365, 2008.

28. Abou-Elhamd KE, Habib TN, Moussa AE and Badawy BS: The role of genetic susceptibility in head and neck squamous cell carcinoma. Eur Arch Otorhinolaryngol 265: 217-222, 2008.

29. Scully C. Field JK and Tanzawa H: Genetic aberrations in oral or head and neck squamous cell carcinoma 2: Chromosomal aberrations. Oral Oncol 36: 311-327, 2000

30. Lagos-Quintana M, Rauhut R, Meyer J, Borkhardt A and Tuschl T: New microRNAs from mouse and human. RNA 9: 175-179, 2003

31. Wang FE, Zhang C, Maminishkis A, Dong L, Zhi C, Li R, Zhao J, Majerciak V, Gaur AB, Chen S and Miller SS: MicroRNA-204/211 alters epithelial physiology. FASEB J 24: 1552-1571, 2010.

32. Gong M, Ma J,Li M,Zhou M,Hock JM and Yu X: MicroRNA-204 critically regulates carcinogenesis in malignant peripheral nerve sheath tumors. Neuro Oncol 14: 1007-1017, 2012

33. Garzon R, Garofalo M, Martelli MP, Briesewitz R, Wang L, Fernandez-Cymering C, Volinia S, Liu CG, Schnittger S, Haferlach T, et al: Distinctive microRNA signature of acute myeloid leukemia bearing cytoplasmic mutated nucleophosmin. Proc Natl Acad Sci USA 105: 3945-3950, 2008.
34. Mikhaylova O, Stratton Y, Hall D, Kellner E, Ehmer B, Drew AF, Gallo CA, Plas DR, Biesiada J, Meller J and Czyzyk-Krzeska MF: VHL-regulated MiR-204 suppresses tumor growth through inhibition of LC3B-mediated autophagy in renal clear cell carcinoma. Cancer cell 21: 532-546, 2012

35. Huang J, Zhao L, Xing L and Chen D: MicroRNA-204 regulates Runx2 protein expression and mesenchymal progenitor cell differentiation. Stem cells 28: 357-364, 2010.

36. Courboulin A, Paulin R, Giguère NJ, Saksouk N, Perreault T, Meloche J, Paquet ER, Biardel S, Provencher S, Côté J, et al: Role for miR-204 in human pulmonary arterial hypertension. J Exp Med 208: 535-548, 2011.

37. Conte I, Carrella S, Avellino R, Karali M, Marco-Ferreres R, Bovolenta P and Banfi S: miR-204 is required for lens and retinal development via Meis2 targeting. Proc Natl Acad Sci USA 107: 15491-15496, 2010

38. Natera-Naranjo O, Aschrafi A, Gioio AE and Kaplan BB: Identification and quantitative analyses of microRNAs located in the distal axons of sympathetic neurons. RNA 16: 1516-1529, 2010.

39. Lee Y, Yang X, Huang Y, Fan H, Zhang Q, Wu Y, Li J, Hasina R, Cheng C, Lingen MW, et al: Network modeling identifies molecular functions targeted by miR-204 to suppress head and neck tumor metastasis. PLoS Comput Biol 6: e1000730, 2010

40. Chung TK, Lau TS, Cheung TH, Yim SF, Lo KW, Siu NS, Chan LK, Yu MY, Kwong J, Doran G, et al: Dysregulation of microRNA-204 mediates migration and invasion of endometrial cancer by regulating FOXC1. Int J Cancer 130: 1036-1045, 2012.

41. Ryan J, Tivnan A, Fay J, Bryan K, Meehan M, Creevey L, Lynch J, Bray IM, O'Meara A, Tracey L, et al: MicroRNA-204 increases sensitivity of neuroblastoma cells to cisplatin and is associated with a favourable clinical outcome. Br J Cancer 107: 967-976, 2012.

42. Ying Z, Li Y, Wu J, Zhu X, Yang Y, Tian H, Li W, Hu B, Cheng SY and Li M: Loss of miR-204 expression enhances glioma migration and stem cell-like phenotype. Cancer Res 73: 990-999, 2013.

43. Penzo-Mendez AI: Critical roles for SoxC transcription factors in development and cancer. Int J Biochem Cell Biol 42: 425-428, 2010.

44. Gunes S, Yegin Z, Sullu Y, Buyukalpelli R and Bagci H: SOX4 expression levels in urothelial bladder carcinoma. Pathol Res Pract 207: 423-427, 2011

45. Hur W, Rhim H, Jung CK, Kim JD, Bae SH, Jang JW, Yang JM, Oh ST, Kim DG, Wang HJ, et al: SOX4 overexpression regulates the p53-mediated apoptosis in hepatocellular carcinoma: Clinical implication and functional analysis in vitro. Carcinogenesis 31: 1298-1307, 2010

46. Aaboe M, Birkenkamp-Demtroder K, Wiuf C, Sørensen FB, Thykjaer T, Sauter G, Jensen KM, Dyrskjøt L and Ørntoft T: SOX4 expression in bladder carcinoma: Clinical aspects and in vitro functional characterization. Cancer Res 66: 3434-3442, 2006.

47. Jang SM, Kang EJ, Kim JW, Kim CH, An JH and Choi KH: Transcription factor Sox 4 is required for PUMA-mediated apoptosis induced by histone deacetylase inhibitor, TSA. Biochem Biophys Res Commun 438: 445-451, 2013.

48. Jafarnejad SM, Wani AA, Martinka M and Li G: Prognostic significance of Sox4 expression in human cutaneous melanoma and its role in cell migration and invasion. Am J Pathol 177: 2741-2752, 2010.

49. Liao YL, Sun YM, Chau GY, Chau YP, Lai TC, Wang JL, Horng JT, Hsiao M and Tsou AP: Identification of SOX4 target genes using phylogenetic footprinting-based prediction from expression microarrays suggests that overexpression of SOX4 potentiates metastasis in hepatocellular carcinoma. Oncogene 27: 5578-5589, 2008

50. Pramoonjago P, Baras AS and Moskaluk CA: Knockdown of Sox 4 expression by RNAi induces apoptosis in ACC3 cells. Oncogene 25: 5626-5639, 2006. 